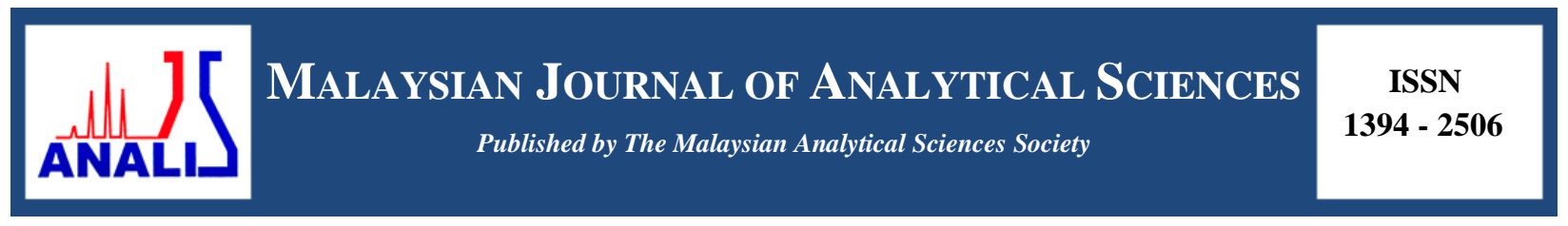

\title{
SYNTHESIS AND MOLECULAR DOCKING OF 2,4,5-TRISUBSTITUTED- 1,3-THIAZOLE DERIVATIVES AS ANTIBACTERIAL AGENTS
}

\author{
(Sintesis dan Penyatuan Molekul Terbitan 1,3-Tiazol Berpenggantian-2,4,5 Sebagai Agen \\ Antibakteria)
}

Iswatun Hasanah Abdullah Ripain ${ }^{1}$, Norashikin Roslan ${ }^{1}$, Nurul Shazana Norshahimi ${ }^{1}$, Siti Salwa Mohamed Salleh ${ }^{1}$, Noraslinda Muhamad Bunnori ${ }^{2}$, Nurziana $\operatorname{Ngah}^{1 *}$

${ }^{1}$ Department of Chemistry, Kulliyyah of Science

${ }^{2}$ Department of Biotechnology, Kulliyyah of Science

International Islamic University Malaysia, Kuantan Campus, Bandar Indera Mahkota, 25200 Kuantan, Pahang, Malaysia

*Corresponding author: nurziana@iium.edu.my

Received: 19 August 2018; Accepted: 18 February 2019

\begin{abstract}
The emergence of antibiotic resistance against bacterial strains has attracted great interest in the discovery and development of new antibacterial agents. Thiazole derivatives have been widely used in the biological as well as pharmacological fields and their efficiency as pharmaceutical drugs are well established. In this study, a series of thiazole derivatives were synthesized in reaction between 3-chloroacetyl acetone and ammonium thiocyanate followed by incorporating selected amines in one-pot synthesis manner. The compounds were structurally characterized by Fourier Transform Infrared (FTIR), Proton Nuclear Magnetic Resonance ( ${ }^{1} \mathrm{H}$ NMR), Ultraviolet-Visible (UV-Vis) and Gas Chromatography-Mass Spectrometry (GC-MS). Their antibacterial properties were screened using disc diffusion technique against selected Gram-positive (Bacillus cereus and Staphylococcus epidermidis) as well as Gram-negative bacteria (Escherichia coli and Pseudomonas aeruginosa) with T3 exhibited the most potent antibacterial activity. Molecular docking studies were also performed against Glucosamine-6-phosphate (GlcN-6-P) synthase which is known as the essential building block of most bacteria. The docking result displayed that $\mathbf{T 3}$ exhibited the minimum binding energy of $-7.09 \mathrm{kcal} \mathrm{mol}^{-1}$ as compared to $\mathbf{T 1}$ and $\mathbf{T} 2$ with -6.49 and $-6.76 \mathrm{kcal} \mathrm{mol}^{-1}$, respectively which is in agreement with antibacterial result. The output of this preliminary study will contribute in structural enhancement in drug discovery.
\end{abstract}

Keywords: thiazole derivatives, antibacterial, disc diffusion, molecular docking, GlcN-6-P synthase

\begin{abstract}
Abstrak
Kewujudan rintangan terhadap bakteria telah menarik minat dalam penemuan dan perkembangan agen antibakteria yang terkini. Terbitan tiazol telah digunakan dengan meluas dalam bidang biologi dan farmakologi di mana keberkesanannya sebagai ubat farmaseutikal telah ditemui. Dalam kajian ini, terbitan tiazol telah disintesis dengan menindakbalaskan $\alpha$-haloketon (3-kloroasetil aseton), ammonium tiosianat dan beberapa sebatian amina terpilih secara sintesis satu pot. Produk tindak balas yang terhasil telah dicirikan dengan Transformasi Fourier-Inframerah (FTIR), Proton Resonans Magnet Nukleus ( ${ }^{1} \mathrm{H}$ NMR), UltralembayungSinar Nampak (UV-Vis) serta Kromatografi Gas-Spektrometer Jisim (GC-MS). Sifat antibakteria sebatian ini telah disaring menggunakan teknik serapan cakera terhadap bakteria Gram-positif (Bacillus cereus dan Staphylococcus epidermidis) dan Gram-negatif (Escherichia coli dan Pseudomonas aeruginosa) dengan T3 menunjukkan aktiviti antibakteria yang paling berkesan. Penyatuan molekul telah dilakukan terhadap enzim Glukosamina-6-fosfat sintase (GlcN-6-P) yang merupakan unsur binaan penting bagi kebanyakan bakteria. Merujuk kepada keputusan penyatuan molekul, T3 menunjukkan tenaga pengikatan yang paling minima iaitu $-7.09 \mathrm{kcal} \mathrm{mol}^{-1}$ berbanding T1 dan T2 masing-masing pada -6.49 dan $-6.76 \mathrm{kcal} \mathrm{mol}^{-1}$, menunjukkan nilai-nilai ini bersetuju dengan keputusan saringan antibakteria. Keputusan kajian awal ini akan menyumbang kepada penambahbaikan struktur untuk penghasilan ubat.
\end{abstract}


Kata kunci: terbitan tiazol, antibakteria, resapan cakera, penyatuan molekul, GlcN-6-P sintase

\section{Introduction}

Bacteria are described as harmful tiny living things which can cause serious diseases such as diarrhea, infections to intravascular organ, nausea, inflammation and abdominal pain [1,2]. Thus, there is a growing urge to develop treatment system to cure the diseases and one of the main options is in antibiotic field. Synthesized organic compound is turning into most suitable candidate as compared to other options such as inorganic and natural product extract because of its ease of structural design, high percentage yield and reduction of natural resources consumption [3-9]. A major challenge for this approach is to design a suitable compound which can surpass the increasing concern on antibiotic resistance.

In recent years, studies on structural and biological properties of thiazole have been the subject of considerable interest in the field of pharmacological among researchers. Thiazole derivatives were reported to exhibit excellent activities in biological fields such as anti-inflammatory, antifungal, anticancer, antibacterial, anticonvulsant, antiviral and antitumor [9]. Presence of nitrogen and sulphur atoms in thiazole structure has enhanced its physiochemical properties to be biologically active in most pharmacological areas [5]. Besides, incorporating different groups into the core structure of thiazole moiety at 2, 4 and 5-positions were reported to further enhance overall performance in term of efficiency of active site [10].

Furthermore, glucosamine-6-phosphate (GlcN-6-P) synthase represents an interesting protein target because it plays vital role in the protection of cell wall for most microorganisms as well as for human cell [11]. Inactivation of the enzyme in microbial cells significantly decreases population of bacteria without affecting the mammalian cells [12, 13]. Therefore there are a large number of studies on molecular docking for antibacterial agents focusing on GlcN$6-\mathrm{P}$ synthase as their target enzyme $[14,15]$. The potential inhibitor will form interaction with the active site of the enzyme and form a ligand-enzyme complex which is responsible in inhibition mechanism [16]. Thus, molecular docking studies are widely required in this field as the process will provide information on the interaction energy between ligand and target site of the enzyme.

In continuation to this effort, a series of 2, 4, 5-trisubstituted-1, 3-thiazole derivatives (Figure 1) of T1-T3 were synthesized and their usability as antibacterial agents were screened against selected Gram-positive and Gramnegative bacterial strains. Next, in order to further understand the interaction between thiazole derivatives and the significant target enzyme in bacterial strains known as glucosamine-6-phosphate synthase (GlcN-6-P), molecular docking study was applied.

\section{Reagents}

\section{Materials and Methods}

Ammonium thiocyanate, 3-chloroacetyl acetone, 3,4-dichloroaniline, 4-aminophenol, methyl-4-aminobenzoate, acetone, methanol, dichloromethane and dimethyl sulfoxide were purchased from standard commercial suppliers such as Sigma-Aldrich, Merck, Acrós Organics, Fisher Scientific and R \& M Chemical. All chemicals and solvents used in this study were of reagent grade (AR) and used without further purification.

\section{Materials and physical measurements}

Melting points were measured on a Stuart Scientific Melting Point Apparatus SMP3 and were uncorrected. ${ }^{1} \mathrm{H}$ NMR spectra were recorded at $500 \mathrm{MHz}$ on NMR machine Bruker Ultra Shield Plus $500 \mathrm{MHz}$ spectrometer in deuterated dimethyl sulfoxide- $\mathrm{d}_{6}$ (DMSO) using tetramethylsilane (TMS) as an internal standard. The chemical shifts were reported in ppm scale. IR spectra of the compounds were recorded from KBr pellets using Perkin Elmer FTIR GX spectrometer in the spectral range of $4000-400 \mathrm{~cm}^{-1}$. UV-Vis were measured via Shimadzu UV-1601PC Spectrophotometer using methanol as solvent to generate absorption within 200-600 nm to study presence of electronic transition which the compounds might exhibit. The synthesized compounds were dissolved in dichloromethane (DCM) and analyzed using Perkin Elmer GC-MS (Clarus 500 Chromatography/Mass Spectrometry). 


\section{General experimental procedure}

Ammonium thiocyanate $(13 \mathrm{mmol})$ in acetone was added into a solution of 3 -chloroacetyl acetone $(13 \mathrm{mmol})$ in acetone and stirred for $c a .15$ minutes at room temperature. After the formation of white precipitate, an equimolar amount of amine derivatives (13 mmol) in acetone was added drop wise and stirred at refluxed condition for $c a .2$ hours. The reaction was carried out to give yellow solution with white precipitate of salt as by products. After completion, the reaction mixture was cooled to room temperature and filtered. The filtrate was allowed to be evaporated to form precipitate. The product formed was recrystallized from methanol to produce T1-T3. The synthetic route of the synthesized compounds is described in Scheme 1.<smiles>CC(=O)C(Cl)C(C)=O</smiles>

3-chloroacetyl acetone

Where:

T1:<smiles>Cc1ccc(Cl)c(Cl)c1</smiles>

T2:

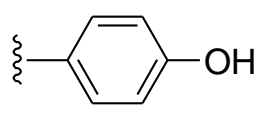

T3:

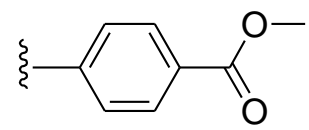

$\mathrm{NH}_{4} \mathrm{SCN}$

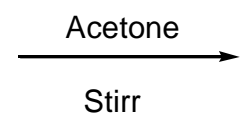

Ammonium thiocyanate

Scheme 1. The general synthetic work-up of thiazole derivatives

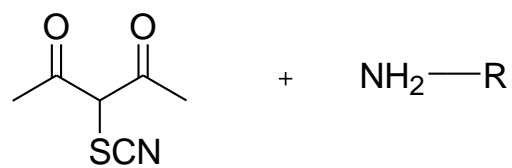

Acyl thiocyanate

Amines

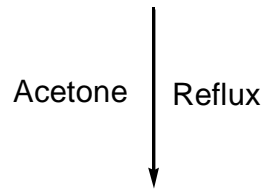<smiles>[R]Nc1nc(C)c(C(C)=O)s1</smiles>

Targeted compounds of T1, T2 and T3

\section{Determination of antibacterial activity}

The antibacterial properties of the synthesized compounds (T1-T3) were screened for their antibacterial activity against Gram-positive bacterial strains (Bacillus cereus and Staphylococcus epidermidis) as well as Gram-negative bacterial strains (Escherichia coli and Pseudomonas aeruginosa) by disc diffusion technique [17]. Synthesized compounds were dissolved in DMSO at concentration of $50 \mathrm{mg} / \mathrm{mL}$ and impregnated on blank discs. The discs were placed on the agar surface pre-inoculated with suspension of bacteria ( $0.5 \mathrm{Mc}$ Farland standards) and incubated for 24 hours at $37^{\circ} \mathrm{C}$. Streptomycin served as antibiotic positive control and solvent blank (DMSO) as negative control respectively. After $18-24$ hours of incubation at $37^{\circ} \mathrm{C}$, the diameter of inhibition zone was observed and measured in $\mathrm{mm}$.

\section{Molecular docking}

The synthesized molecules (T1-T3) were simulated for molecular docking using AutoDock 4.2 package software to investigate their affinity properties to the binding pocket of GlcN-6-P synthase. The enzyme as receptor was obtained from the RCSB Protein Data Bank (1MOQ) in pdb file format (https://www.rcsb.org/structure/1MOQ) and used as a rigid molecule [18]. Hydrogen atoms were added and water molecules were removed from amino acids. All the ligands were drawn using Chem Draw Ultra 7.0 and saved in mol file and the energies of compounds 
were minimized before converted into pdb format via open Babel 2.4.1 software. During docking, the grid dimensions must surround the region of the active site in the macromolecules. The grid box was set at 46,54 and

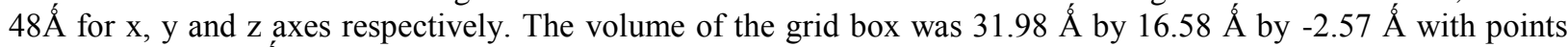
separated by $0.375 \AA$. The grid center was set to $5.472,-6.194$ and -10.694 for $\mathrm{x}, \mathrm{y}$ and $\mathrm{z}$ respectively which covered all the amino acid residues in the active pocket. Lamarckian Genetic Algorithm was applied as the docking algorithm with 100 runs, 150 population size, 27,000 maximum numbers of generations and 2,500,000 maximum numbers of energy evaluation.

\section{Results and Discussion}

Characterization study: 5-acetyl-4-methyl-2-(3, 4-dichloroaniline)-1,3-thiazole (T1)

Yellow solid (2.94 g, 75\%), T1 was prepared from ammonium thiocyanate (1 g, $13 \mathrm{mmol}), 3$-chloroacetylacetone $(1.75 \mathrm{~g}, 13 \mathrm{mmol})$ and 3,4-dichloroaniline $(2.10 \mathrm{~g}, 13 \mathrm{mmol})$ in the same manner as described in Scheme 1, m.p 184.1-185.3 ${ }^{\circ} \mathrm{C} .{ }^{1} \mathrm{H}$ NMR $\left(500 \mathrm{MHz}, \mathrm{DMSO}-\mathrm{d}_{6}\right): \delta_{\mathrm{H}} 2.43\left(\mathrm{~s}, 3 \mathrm{H}, \mathrm{CH}_{3}\right), 2.51\left(\mathrm{~s}, 3 \mathrm{H}, \mathrm{CH}_{3}\right), 7.53(\mathrm{~d}, J 9 \mathrm{~Hz}, 1 \mathrm{H}, \mathrm{Ar}-$ $\mathrm{CH}), 7.59(\mathrm{~d}, J 9 \mathrm{~Hz}, 1 \mathrm{H}, \mathrm{Ar}-\mathrm{CH}), 8.03(\mathrm{~s}, 1 \mathrm{H}, \mathrm{Ar}-\mathrm{CH}), 10.99(\mathrm{~s}, 1 \mathrm{H}, \mathrm{NH}$ of thiazole). IR (KBr pellet): $v(\mathrm{~N}-\mathrm{H}) 3269$ $\mathrm{cm}^{-1}, v(\mathrm{C}-\mathrm{H}) 2924 \mathrm{~cm}^{-1}, v(\mathrm{C}=\mathrm{O}) 1604 \mathrm{~cm}^{-1}, v(\mathrm{C}=\mathrm{N}) 1545 \mathrm{~cm}^{-1}, v(\mathrm{C}-\mathrm{Cl}) 714 \mathrm{~cm}^{-1}, v(\mathrm{C}-\mathrm{S}) 652 \mathrm{~cm}^{-1}$. UV-Vis $(\mathrm{MeOH}): \lambda_{\text {abs }}\left(\mathrm{n}-\pi^{*}\right) 224 \mathrm{~nm}, 21600 \mathrm{M}^{-1} \mathrm{~cm}^{-1} ; \lambda_{\text {abs }}\left(\pi-\pi^{*}\right) 343 \mathrm{~nm}, 62200 \mathrm{M}^{-1} \mathrm{~cm}^{-1}$. M/S: Requires $\mathrm{M}^{+} 299.99$; Found $\mathrm{M}^{+} 300.00, \mathrm{~m} / \mathrm{z}: 285.00,86.00$ and 71.00 .

\section{5-acetyl-4-methyl-2-(4-aminophenol)-1,3-thiazole (T2)}

Brown solid (2.26 g, 70\%), T2 was prepared from ammonium thiocyanate (1 g, $13 \mathrm{mmol}), 3$-chloroacetylacetone $(1.75 \mathrm{~g}, 13 \mathrm{mmol})$ and 4-aminophenol $(1.42 \mathrm{~g}, 13 \mathrm{mmol})$ in the same manner as described in Scheme 1, m.p. 192.3193.4 ${ }^{\circ} \mathrm{C} .{ }^{1} \mathrm{H}$ NMR $\left(500 \mathrm{MHz}, \mathrm{DMSO}-\mathrm{d}_{6}\right): \delta_{\mathrm{H}} 2.38\left(\mathrm{~s}, 3 \mathrm{H}, \mathrm{CH}_{3}\right), 2.62\left(\mathrm{~s}, 3 \mathrm{H}, \mathrm{CH}_{3}\right), 6.78$ (pseudo-d, $J 9 \mathrm{~Hz}, 2 \mathrm{H}, \mathrm{Ar}-$ $\mathrm{CH}), 7.35$ (pseudo-d, $J 9 \mathrm{~Hz}, 2 \mathrm{H}, \mathrm{Ar}-\mathrm{CH}), 9.38$ (s, 1H, NH of thiazole), 10.47 (br s, 1H, OH). IR (KBr pellet): $v(\mathrm{~N}-$ H) $3242 \mathrm{~cm}^{-1}, v(\mathrm{O}-\mathrm{H}) 3135 \mathrm{~cm}^{-1}, v(\mathrm{C}-\mathrm{H}) 2962 \mathrm{~cm}^{-1}, v(\mathrm{C}=\mathrm{O}) 1623 \mathrm{~cm}^{-1}, v(\mathrm{C}=\mathrm{N}) 1596 \mathrm{~cm}^{-1}, v(\mathrm{C}-\mathrm{S}) 723 \mathrm{~cm}^{-1}$. UVVis $(\mathrm{MeOH}): \lambda_{\text {abs }}\left(\mathrm{n}-\pi^{*}\right) 226 \mathrm{~nm}, 50300 \mathrm{M}^{-1} \mathrm{~cm}^{-1} ; \lambda_{\text {abs }}\left(\pi-\pi^{*}\right) 346 \mathrm{~nm}, 69200 \mathrm{M}^{-1} \mathrm{~cm}^{-1}$. M/S: Requires $\mathrm{M}^{+} 248.06$; Found $\mathrm{M}^{+}$248.04, m/z: 233.00, 134.00 and 120.00 .

\section{5-acetyl-4-methyl-2-(methyl-4-aminobenzoate)-1,3-thiazole (T3)}

Yellow solid (2.57 g, 68\%), T3 was prepared from ammonium thiocyanate (1 g, $13 \mathrm{mmol}), 3$-chloroacetylacetone $(1.75 \mathrm{~g}, 13 \mathrm{mmol})$ and methyl-4-aminobenzoate $(1.96 \mathrm{~g}, 13 \mathrm{mmol})$ in the same manner as described in Scheme 1, m.p. $210.7-211.7^{\circ} \mathrm{C} .{ }^{1} \mathrm{H}$ NMR $\left(500 \mathrm{MHz}, \mathrm{DMSO}-\mathrm{d}_{6}\right): \delta_{\mathrm{H}} 2.45\left(\mathrm{~s}, 3 \mathrm{H}, \mathrm{CH}_{3}\right), 2.58\left(\mathrm{~s}, 3 \mathrm{H}, \mathrm{CH}_{3}\right), 3.83\left(\mathrm{~s}, 3 \mathrm{H}, \mathrm{OCH}_{3}\right)$, 7.76 (pseudo-d, $J 9 \mathrm{~Hz}, 2 \mathrm{H}, \mathrm{Ar}-\mathrm{CH}), 7.96$ (pseudo-d, $J 9 \mathrm{~Hz}, 2 \mathrm{H}, \mathrm{Ar}-\mathrm{CH}), 11.13$ (s, 1H, NH of thiazole). IR (KBr pellet): $v(\mathrm{~N}-\mathrm{H}) 3280 \mathrm{~cm}^{-1}, v(\mathrm{C}-\mathrm{H}) 3029 \mathrm{~cm}^{-1}, v(\mathrm{C}=\mathrm{O}) 1711 \mathrm{~cm}^{-1}, v(\mathrm{C}=\mathrm{N}) 1610 \mathrm{~cm}^{-1}, v(\mathrm{C}-\mathrm{S}) 593 \mathrm{~cm}^{-1}$. UV-Vis $(\mathrm{MeOH}): \lambda_{\text {abs }}\left(\mathrm{n}-\pi^{*}\right) 229 \mathrm{~nm}, 21700 \mathrm{M}^{-1} \mathrm{~cm}^{-1} ; \lambda_{\text {abs }}\left(\mathrm{n}-\pi^{*}\right) 284 \mathrm{~nm}, 14900 \mathrm{M}^{-1} \mathrm{~cm}^{-1} ; \lambda_{\text {abs }}\left(\pi-\pi^{*}\right) 352 \mathrm{~nm}, 82200 \mathrm{M}^{-1} \mathrm{~cm}^{-1}$. M/S: Requires $\mathrm{M}^{+}$290.07; Found $\mathrm{M}^{+}$290.08, m/z: 275.00, 247.00, 162.00 and 122.00. Structure of synthesized thiazole derivatives are shown in Figure 1.
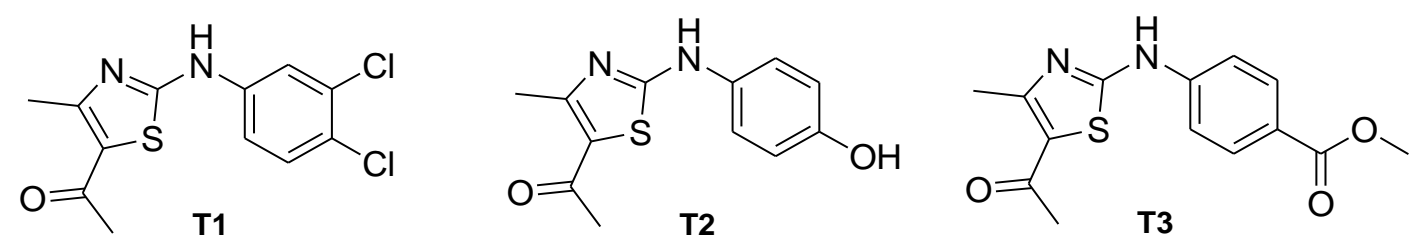

Figure 1. Structure of synthesized thiazole derivatives

A series of thiazole derivatives were successfully synthesized in moderately good yields according to previous literature with some modification [19]. The synthesis of the target compounds was straightforward, and the general synthetic pathway is illustrated in Scheme 1 . Haloketone namely 3-chloroacetyl acetone was reacted with ammonium thiocyanate in acetone to give thiocyanato acetylacetone and ammonium salt as by-product. Next, the amines; 3, 4-dichloroaniline, 4-aminophenol and methyl-4-aminobenzoate were added to the reaction mixture to produce the titled compounds T1, T2 and $\mathbf{T 3}$ respectively. The chemical structure of compounds T1-T3 was proved by spectroscopic and spectrometry data. 
There are five important absorption bands of interest in all IR spectra of T1, T2 and T3 namely $v(\mathrm{~N}-\mathrm{H}), v(\mathrm{C}-\mathrm{H})$, $v(\mathrm{C}=\mathrm{O}), v(\mathrm{C}=\mathrm{N})$ and $v(\mathrm{C}-\mathrm{S})$. The first band was assigned as $\mathrm{N}-\mathrm{H}$ stretching and can be observed in the region of $3280-3242 \mathrm{~cm}^{-1}$ as previously reported [20]. C-H stretching can be observed at typical range between $3029 \mathrm{~cm}^{-1}$ and $2924 \mathrm{~cm}^{-1}$. As reported in literature studies [21,22], $\mathrm{C}=\mathrm{O}$ absorption band at $1711-1604 \mathrm{~cm}^{-1}$ appears as intense peak as a result of high dipole moment due to large partial negative charge of oxygen. Meanwhile, $\mathrm{C}=\mathrm{N}$ and $\mathrm{C}-\mathrm{S}$ stretching bands are observed at $1610-1545 \mathrm{~cm}^{-1}$ and $723-593 \mathrm{~cm}^{-1}$ respectively. Figure 2 shows the FTIR spectrum of 5-acetyl-4-methyl-2-(methyl-4-aminobenzoate)-1,3-thiazole (T3) as representative of this series.

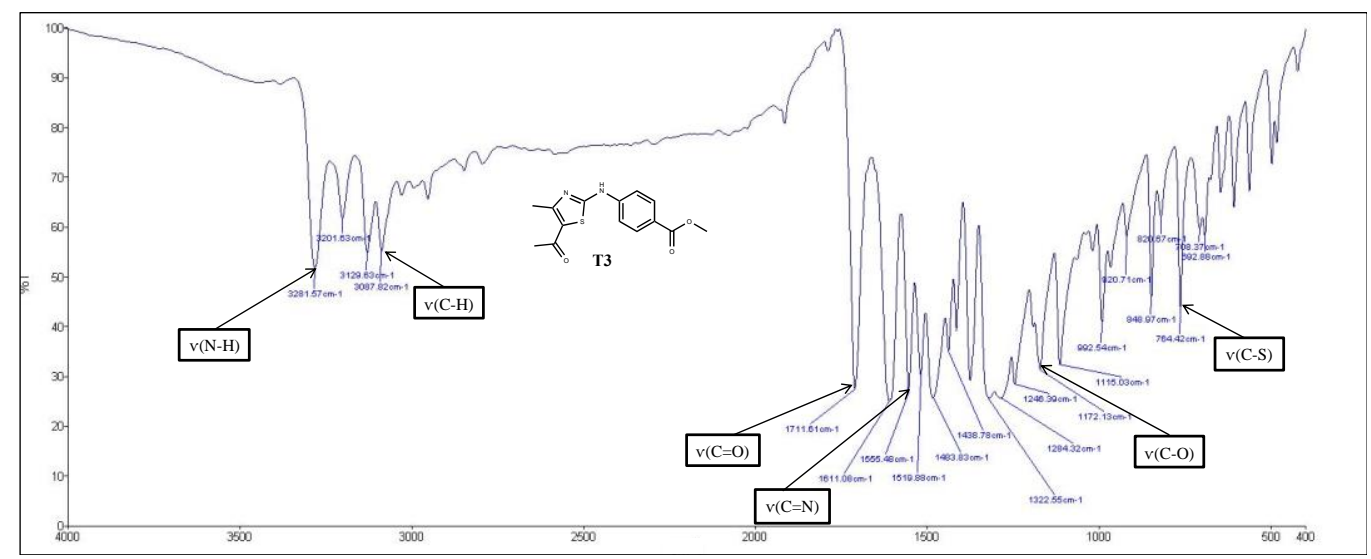

Figure 2. FTIR spectrum of 5-acetyl-4-methyl-2-(methyl-4-aminobenzoate)-1,3-thiazole (T3)

Meanwhile in ${ }^{1} \mathrm{H}$ NMR, two high intensity singlet resonances at $\delta_{\mathrm{H}} 2.38-2.58$ ppm represent two methyl moieties presented in all synthesized compounds (T1-T3). One of the observed resonances is found to be at higher chemical shift region due to deshielding effect of neighbouring $\mathrm{C}=\mathrm{O}$ moiety [23]. In the range of $\delta_{\mathrm{H}} 7.95-6.78 \mathrm{ppm}$, roofing effect due to para substituted phenyl group can be observed in T2 and T3 [24]. However, different pattern at $\delta_{\mathrm{H}}$ 8.02-7.52 ppm is observed due to presence of tri-substituted phenyl in T1. The presence of NH resonance peaks as observed in all ${ }^{1} \mathrm{H}$ NMR spectra prove that the thiazole derivatives were successfully synthesized. NH resonance which appears as singlet is found to be at the most downfield region $\left(\delta_{\mathrm{H}} 11.13-10.46 \mathrm{ppm}\right)$ [25]. Figure 3 shows the ${ }^{1} \mathrm{H}$ spectrum of 5-acetyl-4-methyl-2-(methyl-4-aminobenzoate)-1,3-thiazole (T3) as representative of the group.

In addition to the compounds characterization, UV-Vis spectra of T1-T3 were recorded below than $400 \mathrm{~nm}$. All compounds exhibited similar UV band profile which comprised of two absorption bands with different intensity. The first band at 224-229 nm which is the lowest intensity absorption band $\left(\varepsilon=21600-50300 \mathrm{M}^{-1} \mathrm{~cm}^{-1}\right)$ was assigned as $n-\pi^{*}$ transition which attributed by lone pair of $\mathrm{C}=\mathrm{O}, \mathrm{N}-\mathrm{H}$ and $\mathrm{OH}$ [26]. Besides that, second absorption band which can observed at 343-352 nm was attributed as higher intensity compared $\left(\varepsilon=62200-82200 \mathrm{M}^{-1} \mathrm{~cm}^{-1}\right)$ to the first absorption band. It is due to the electronic transition produced from excitation of unsaturated moiety in a molecular structure [27]. Plus, excitation of $\pi$ electrons from lower to higher energy levels by several unsaturated chromophores such as aromatic and carbonyl moieties was responsible for the transition [28]. 


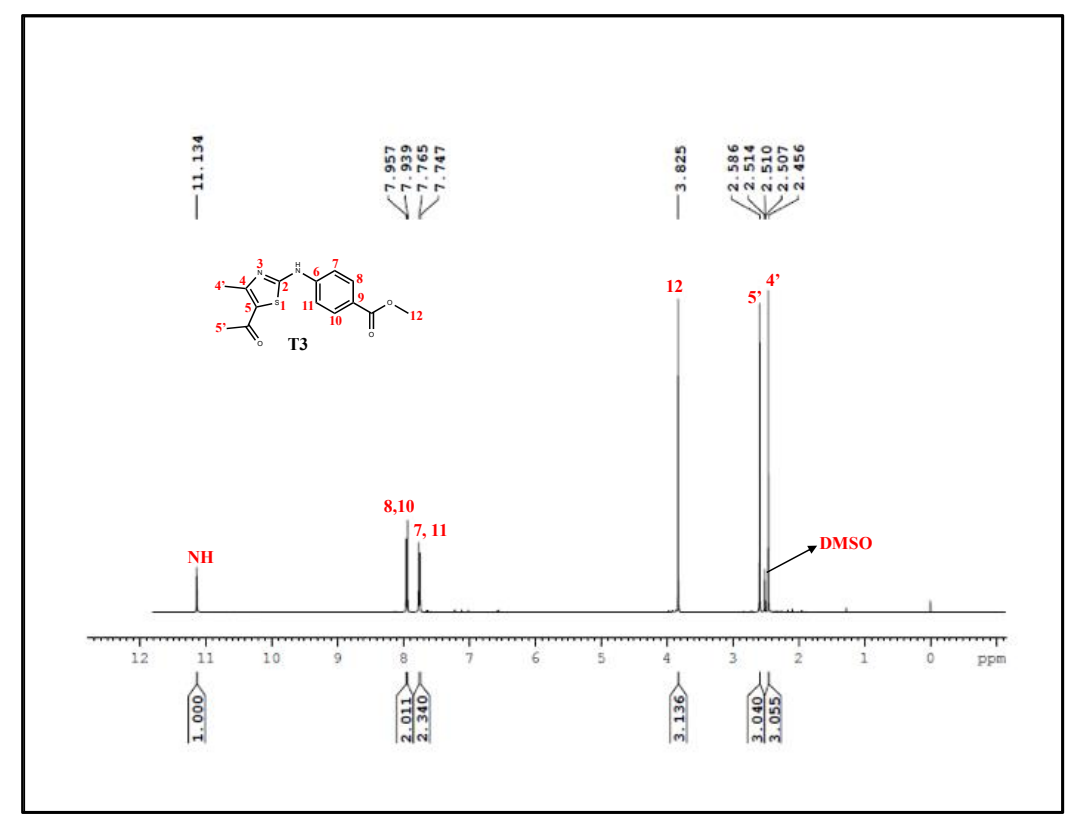

Figure 3. ${ }^{1} \mathrm{H}$ NMR spectrum of 5-acetyl-4-methyl-2-(methyl-4-aminobenzoate)-1,3-thiazole (T3)

\section{Antibacterial activities}

In this work, antibacterial screening test were used as preliminary evaluation. The screening was conducted by measuring the potential of these compounds to retard the growth of bacterial strains as show in Table 1. From the results obtained, it is shows that $\mathbf{T 3}$ exhibited the excellent inhibitory growth against both Gram-positive (S. cereus and $S$. epidermidis) and Gram-negative (E. coli and P. aeruginosa) bacterial strains followed by $\mathbf{T} 2$ and T1. The highest activity showed by $\mathbf{T 3}$ might be due to the presence of electron donating group which is methoxy $\left(\mathrm{OCH}_{3}\right)$, which enhance its interaction towards the tested bacteria. Incorporation of methoxy group in the thiazole compound has boosted the antimicrobial activity in terms of increase in lipophilicity behavior that easily penetrated into the membrane of bacterial strains [29]. Besides, methoxy group also provides electron donating behaviour which enhanced the overall antibacterial activity of the synthesized compound [30]. Conversely, presence of electron withdrawing groups such as hydroxyl and chloro substituents in T1 and T2 weaken overall antibacterial performance.

Table 1. Diameter of clearing zone $(\mathrm{mm})$ around the disc for bacterial strains

\begin{tabular}{lcccc}
\hline \multirow{2}{*}{ Compounds } & \multicolumn{4}{c}{ Zone of inhibition (mm) } \\
\cline { 2 - 5 } & \multicolumn{2}{c}{ Gram-positive bacteria } & Gram-negative bacteria \\
\cline { 2 - 5 } & B. cereus & S. epidermidis & E. coli & P. aeruginosa \\
\hline T1 & 8.7 & 9.0 & 8.0 & 7.0 \\
T2 & 10.0 & 11.0 & 8.3 & 8.7 \\
T3 & 12.0 & 11.0 & 8.5 & 10.0 \\
DMSO & - & - & - & - \\
Streptomycin & 20.0 & 21.0 & 18.0 & 19.0 \\
\hline
\end{tabular}

\section{Molecular docking}

Considering the data obtained from the antibacterial screening result, it is worth to perform molecular docking study. Therefore, molecular docking studies were carried out to know the interaction of synthesized compounds 
(T1-T3) against active site of glucosamine-6-phosphate synthase (GlcN-6-P) which is the target for antibacterial agents. GlcN-6-P synthase is considered as primary target because it is essential building block of bacteria which involves in biosynthesis of cell wall in most of bacteria and fungi [31,32]. Inhibition of this enzyme will restrain the production cell membrane and significantly decrease population of bacteria [33].

In this experiment, orientation of inhibitors interaction in the active site of GlcN-6-P was determined by automated docking [34]. Figure 4 illustrates the best generated conformers for T1-T3 and streptomycin molecules inside the binding pocket of GlcN-6-P synthase.
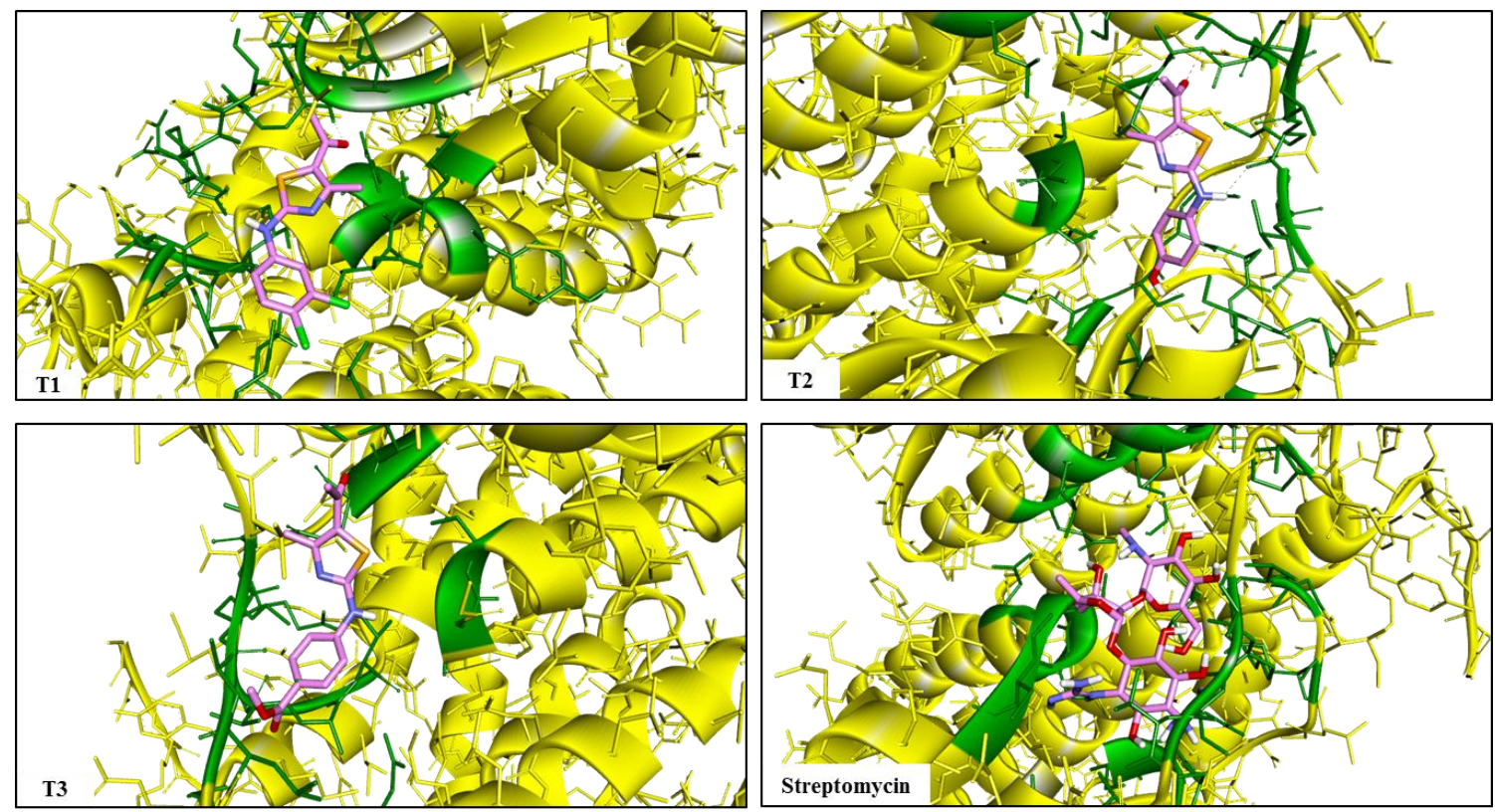

Figure 4. Docked conformations of thiazole derivatives (T1-T3) and standard drug (thick stick model) in the active site of GlcN-6-P synthase (thin stick and solid ribbon model)

The docking ligand molecules T1-T3 with enzyme revealed that all the expected inhibitor compounds exhibiting the hydrogen bonding interactions with more than one amino acid residues in the active pockets of GlcN-6-P synthase which are showed in Figure 5. From the chemical structure of ligands, it can be observed that oxygen atom of

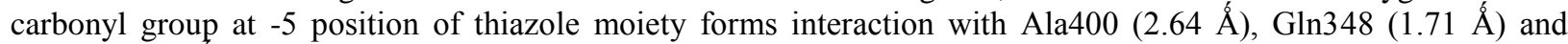
Ser347 $(2.07 \AA)$. Besides that, the amine group in all thiazole derivatives form hydrogen bonding with amino acid

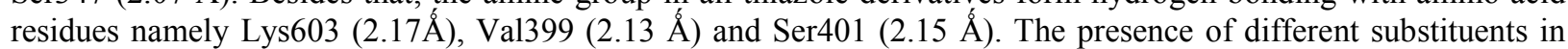
each phenyl moiety of thiazole derivatives which is chloro, hydroxyl and ester groups, respectively affects the interaction performance of ligands towards amino acid residues. For instance, hydroxyl atom that is attached to the phenyl group in T2 tends to form hydrogen bonding with Thr355 (2.30 $\AA$ ). Meanwhile, both oxygen atoms of ester group in T3 form hydrogen bonding with Ala400 (1.45 ̊́) and Val399 (1.90 ̊́).

Furthermore, based on molecular docking prediction in Table 2 below, T3 exhibited the best performance against the target enzyme as supported by its lowest binding energy $\left(-7.09 \mathrm{kcal} \mathrm{mol}^{-1}\right)$ as compared to other ligands and as reported by other studies that state low binding energy is required for inhibition of enzyme $[14,35]$. More negative binding energy is proportional to the activation energy for inhibition reaction which leads to tight binding of enzyme-inhibitor complex [16]. Meanwhile, T1 and T2 showed higher binding energy compared to T3 which coincide with the antibacterial screening result. The result proved that higher binding energy of $\mathbf{T 1}$ and $\mathbf{T} 2$ towards enzyme is reflected in lower antibacterial activity in screening test. This computational prediction is in a very good agreement to antibacterial screening result which proves the significant impact of this molecular docking study. 

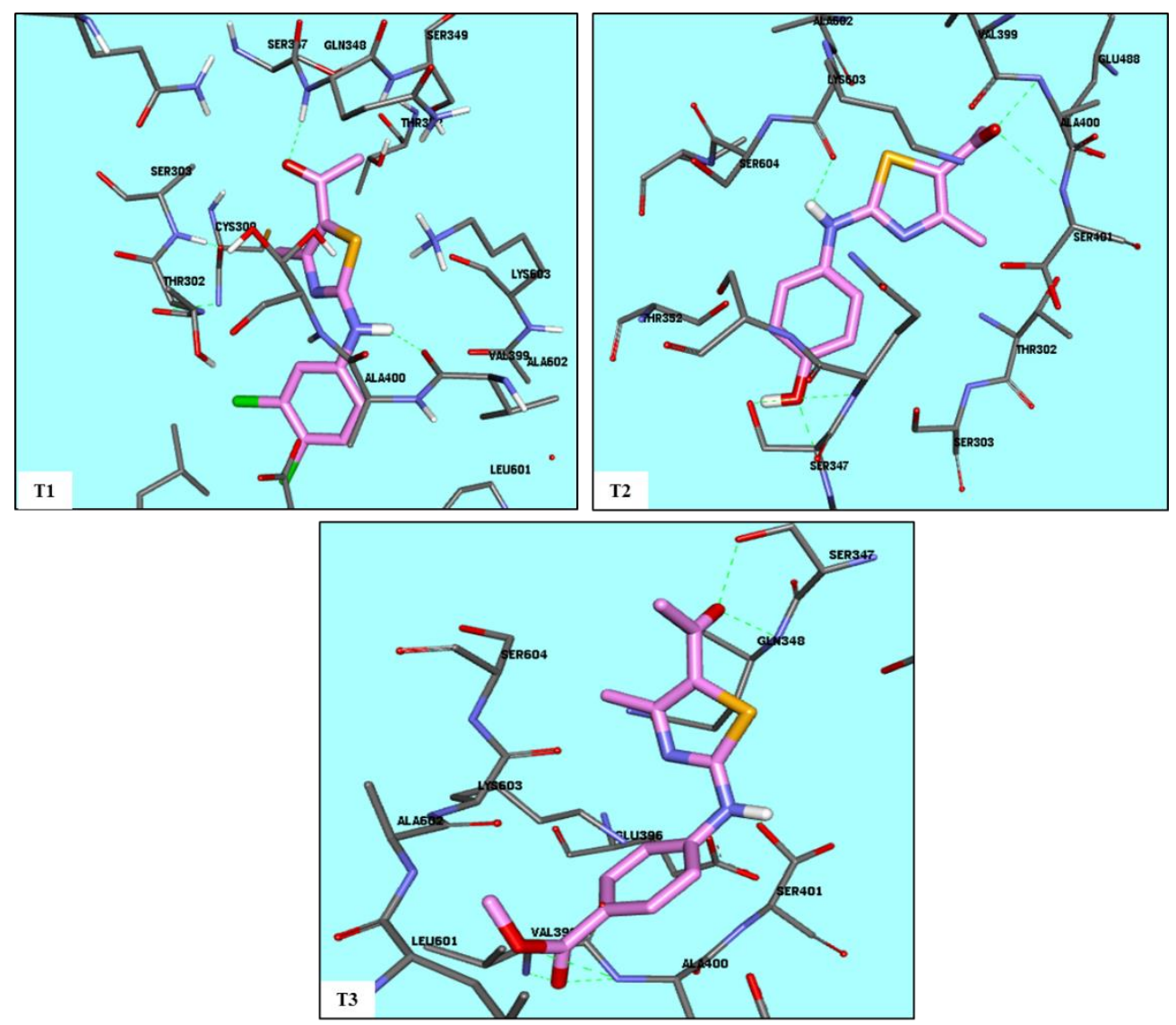

Figure 5. 3D view of all synthesized compounds (ligands) after molecular docking into the active site of GlcN-6-P synthase. Both ligands and amino acid residues of protein are presented in stick in size of 0.2 and 0.1 respectively. Bond length was found less than $3.0 \AA$ in all interactions

Table 2. Molecular docking parameters of T1-T3 and standard drug towards GlcN-6-P synthase

\begin{tabular}{lcl}
\hline Ligand & $\begin{array}{c}\text { Binding Energy } \\
\left(\mathbf{k c a l ~ m o l}^{\mathbf{1}} \mathbf{)}\right.\end{array}$ & Amino acid residues \\
\hline T1 & -6.49 & Gly348, Val399 \\
T2 & -6.76 & Ala400, Lys603, Thr355, Ser347 \\
T3 & -7.09 & Gln348, Ser347, Val399, Ala400, Ser401 \\
Streptomycin (Std.) & -7.66 & Val399, Ser401, Cys300, Ala602, Asn600, Thr302, Glu488 \\
\hline
\end{tabular}

\section{Conclusion}

In conclusion, the present work has demonstrated that series of 2, 4, 5- trisubstituted-1,3-thiazole derivatives (T1T3) were successfully synthesized in moderately good yield as well as characterized using different techniques and exhibited potential activity against the tested bacterial strains. Among the tested compounds, 5-acetyl-4-methyl-2(methyl-4-aminobenzoate)-1, 3-thiazole (T3) has emerged as most active against tested bacterial strains. Molecular docking studies also revealed that $\mathbf{T 3}$ has the lowest binding energy and may consider as a good inhibitor of GlcN6-P synthase. For further investigation, complete antimicrobial procedure including in vitro assays should be 
applied to evaluate the potential of thiazole derivatives against different types of bacteria and fungi with the support of molecular docking study.

\section{Acknowledgement}

We gratefully acknowledge grants from the Ministry of Education Malaysia FRGS14-15-0392, Department of Chemistry and Biotechnology, Kulliyyah of Science, International Islamic University Malaysia (IIUM) for providing the essential laboratory facilities. We also would like to thank the Central Laboratory, Universiti Malaysia Pahang for NMR services.

\section{References}

1. Tran, T., Nguyen, T., Do, T., Huynh, T., Tran, C. and Thai, K. (2012). Synthesis and antibacterial activity of some heterocyclic chalcone analogues alone and in combination with antibiotics. Molecules, 17(6): $6684-$ 6696.

2. Kotb, E. R., Anwar, M. M., Abbas, H. S. and El-Moez, S. I. A. (2013). A concise synthesis and antimicrobial activity of a novel series of naphthylpyridine-3-carbonitrile compounds. Acta Poloniae Pharmaceutica-Drug Research, 70(4): $667-679$.

3. Ejideke, I. P. and Ajibade, P. A. (2015). Synthesis, characterization, antioxidant and antibacterial studies of some metal (II) complexes of tetradentate Schiff base ligand: (4E)-4-[(2-\{(E)-[1-(2,4-dihydroxyphenyl) ethylidene] amino \}ethyl)imino]penta-2-one. Bioinorganic Chemistry and Applications, 9: 1 - 9.

4. Dayt, D. and Serra, G. (2010). Thiazole and oxazole alkaloids: Isolation and synthesis. Marine Drugs, 8: 2755 -2780 .

5. Kaur, K., Kaur, R. and Dhir, G. N. (2014). Synthesis and biological of amino acid and peptide conjugates of Rhein derivatives. Journal of Advanced Pharmaceutical Education and Resource, 4(3): 311 - 318.

6. Penta, S. and Vedula, R. R. (2012). A facile one-pot synthesis of thiazole-pyrazole derivatives via multicomponent approach. Organic Communications, 5(3): 143 - 149.

7. Bodireddy, M. R., Mohinuddin, P. M. K., Gundala, T. R. and Reddy, G. (2016). Lactic acid-mediated tandem one-pot synthesis of 2-aminothiazole derivatives: A rapid, scalable and sustainable process. Organic Chemistry, 2: $1-13$.

8. Kołazcek, A., Fusiarz, I., Ławecka, J. and Braowska, D. (2014). Biological activity and synthesis of sulfonamide derivatives: A brief review. Chemik Er Zeitung, 68(7): 620 - 628.

9. Kushwara, N., Kushwara, S. K. S. and Rai, A. K. (2012). Biological activities of thiadiazole derivatives: A review. International Research of Chemtech Research, 4(2): $517-531$.

10. Vijesh, A. M., Isloor, A. M., Telkar, S., Arulmoli, T. and Fun, H. K. (2013). Molecular docking studies of some new imidazole derivatives for antimicrobial properties. Arabian Journal of Chemistry, 6: 197- 204.

11. Pawlak, D., Stolarska, M., Wojciechowski, M. and Andruszkiewicz, R. (2015). Synthesis, anticandial activity of $\mathrm{N}^{3}$-(4-methoxyfumaroyl) -(S)-2,3-diaminopropanoic amide derivatives-novel inhibitors of glucosamine-6phosphate synthase. European Journal of Medicinal Chemistry, 90: 577 - 582.

12. Milewski, S. (2012). Glucosamine-6-phosphate synthase -the multi-facets enzyme. Biochimica et Biophysica Acta-Protein Structure and Molecular Enzymology, 1597(2): 173 -192.

13. Aouad, M. R., Mayaba, M. M., Naqvi, A., Bardaweel, S. K., Al-blewi, F. F., Messali, M. and Rezki, N. (2017). Design, synthesis, in silico and in vitro antimicrobial screenings of novel 1,2,4- triazoles carrying 1,2,3-triazole scaffold with lipophilic side chain tether. Chemistry Central Journal, 11(1): 1-13.

14. Krishna, B. G., Sarojini, B. K. and Darshanraj, C. G. (2010). Synthesis, characterization, molecular docking and evaluation of antibacterial, antiproliferative and anti-inflammatory properties of new pyridinyl substituted triazole derivatives. Der Pharma Chemica, 6(4): 345 - 361.

15. Rajasekaran, A., Sivakumar, K. K., Sureshkumar, K. and Manjushree, M. (2017). Design, synthesis, characterization and in-vitro antimicrobial activity of some hybridized triazole scaffolds. Future Journal of Pharmaceutical Sciences, 3(1): 1 - 10.

16. Tian, G. and Haffner, C. D. (2001). Linear relationships between binding energy of time-dependent inhibition of steroid $5 \alpha$-reductase by $\chi^{1}$-4-azasteroids. The Journal of Biological Chemistry, 276(24): 21359 - 21364.

17. Koochak, H., Seyyednejad, S. M. and Motamedi, H. (2010). Preliminary study on the antibacterial activity of some medicinal plants of Khuzestan (Iran). Asian Pacific Journal of Tropical Medicine, 3(3): 180 - 184. 
18. Mouilleron, S., Badet-Deisot, M. A. and Golielli-Pimpaneau, B. (2008). Ordering of C-terminal loop and glutaminase domains of glucosamine-6-phosphate synthase promotes sugar ring opening and formation of the ammonia channel. Journal of Molecular Biology, 377(4): 1174 - 1185.

19. Jumal, J., Latip, J. and Yamin, B. M. (2006). 2-(4-fluoroanilino)-4,5-dimethyl-1,3-thiazole. Acta Crystallographica Section E Structure Report Online, 62(4): 3305 - 3306.

20. Patel, D. D., Patel, M. S., Patel, V. S. and Patel, K. C. (2014). Synthesis and benzothiazole derivatives, their Schiff bases and its anti-infective biological activities. International Journal of Advanced Research, 2 (3): 1048 -1054 .

21. Rawal, R. K., Tripathi, R., Katti, S. B., Pannecouque, C. and Clercq, E. D. (2008). Design and synthesis of 2(2,6-dibromophenyl)-3-heteroaryl-1,3-thiazolidin-4-nes as anti-HIV agents. European Journal of Medicinal Chemistry, 43: 2800 - 2806.

22. Khattab, S. N. (2005). Synthesis and biological activity of novel amino acid-( $n$ '-benzoyl) hydrazine and amino acid-(n'-nicotinoyl) hydrazine derivatives. Molecules, 10: 1218 - 1228.

23. Luzina, E. L. and Popov, A. V. (2009). Synthesis and anticancer activity of n-bis(trifluoromethyl)alkyl-n'thiazolyl and $n$-bis(trifluoromethyl)alkyl-n'-benzothiazolyl ureas. European Journal of Medicinal Chemistry, 44 (2009): $4944-4953$.

24. Upmanyu, N., Kumar, S., Shah, K. and Mishra, P. (2012). synthesis and antimicrobial studies of some 4(substituted)-ethanoylamino-3-mercapto-5-(4-substituted) phenyl-1, 2, 4-triazoles. Dhaka University Journal of Pharmaceutical Sciences, 11(1): 7 - 18.

25. Anbazhagan, R. and Sankaran, K. R. (2013). Syntheses, spectral characterization, single crystal X-ray diffraction and DFT computational studies of novel derivatives. Journal of Molecular Structure, 1050: 73 - 80.

26. Nalwa, H. S., Hanack, M., Pawlowski, G. and Engel, M. K. (1999). Third-order nonlinear optical properties of porphyrazine, phthalocyanine and naphthalocyanine germanium derivatives: demonstrating the effect of $\pi$ conjugation length on third-order optical nonlinearity of two-dimensional molecules. Chemical Physics, 245: $17-26$.

27. Qiao, L. and Hao, S. (2018). Novel trifluoromethylcoumarinyl urea derivatives: synthesis, characterization, fluoroscence, and bioactivity. Molecules, 23(600): 1 - 14.

28. Saylam, A., Seferoglu, Z. and Ertan, N. (2008). Synthesis of new hetarylazoindole dyes from some 2aminothiazole derivatives. Russian Journal of Organic Chemistry, 44(4): 587 - 594.

29. Arora, P., Narang, R., Bhatia, S., Nayak, S. K., Singh, S., K. and Narasimhan, B. (2015). Synthesis, molecular docking and QSAR studies of 2, 4-disubsituted thiazoles as antimicrobial agents. Journal of Applied Pharmaceutical Science, 5(2): $28-42$.

30. Majik, M. S., Rodrigues, C., Mascarenhas, S. and Souza, L. D. (2014). Bioorganic chemistry design and synthesis of marine natural product-based $1 \mathrm{H}$-indole-2, 3-dione scaffold as a new antifouling/ antibacterial agent against fouling bacteria. Bioorganic Chemistry, 54: 89-95.

31. Shia, J. S., Al-Bayati, R. I. H., Abdula, A. M. and Saour, K. Y. (2015). Docking study of some N-[4-(4arylidene)-2-(4-substituted-phenyl)-5-oxo-4, 5-dihydro-imidazol-1-yl] benzenesulfonamide derivatives against glucosamine-6-phosphate synthase. International Journal of Chemical Sciences, 13(4): 1982 - 1990.

32. Venkatesh, T., Bodke, Y. D., Kenchappa, R. and Telkar, S. (2016). Synthesis, antimicrobial and antioxidant activity of chalcone derivatives containing thiobarbitone nucleus. Medicinal Chemistry, 6 (7): 440 - 448.

33. Fikrika, H., Ambarsari, L. and Sumaryada, T. (2009). Molecular docking studies of catechin and its derivatives as anti-bacterial inhibitor for glucosamine-6-phosphate synthase. Earth and Environmental Science, 31: 1 - 6.

34. Sarojini, B. K., Krishna, B. G., Darshanraj, C. G., Bharath, B. R. and Manjunatha, H. (2010). Synthesis, characterization, in vitro and molecular docking studies of new 2, 5-dichloro thienyl substituted thiazole derivatives for antimicrobial properties. European Journal of Medicinal Chemistry, 45(8): 3490 - 3496.

35. Venkatesh, T., Bodke, Y. D., Kenchappa, R. and Telkar, S. (2016). Synthesis, antimicrobial and antioxidant activity of chalcone derivatives containing thiobarbitone nucleus. Medicinal Chemistry, 6(7): 440 - 448. 